\title{
Lobar haemorrhagic mass in a young girl with neurofibromatosis type 1
}

\author{
Rita Ceponiene, ${ }^{1}$ Michael L Levy, ${ }^{2}$ John Ross Crawford ${ }^{3}$
}

${ }^{1}$ Department of Neurosciences, University of California San Diego, La Jolla, California, USA ${ }^{2}$ Department of Neurosurgery, University of California San Diego, San Diego, California, USA

${ }^{3}$ Department of Neurosciences and Pediatrics, University of California San Diego, San Diego, California, USA

Correspondence to Dr John Ross Crawford, jrcrawford@ucsd.edu
To cite: Ceponiene $\mathrm{R}$, Levy ML, Crawford JR. BM Case Rep Published online: [please include Day Month Year] doi:10.1136/bcr-2013200565

\section{DESCRIPTION}

A 9-year-old girl with neurofibromatosis type 1 (NF-1) presented with sudden onset neurological deterioration following a 2-day history of headache. She was comatose on arrival with right third nerve palsy and contralateral hemiparesis. A head CT revealed a large right frontal acute haemorrhagic lesion with midline shift and uncal herniation (figure 1). The patient underwent emergent decompressive craniotomy and resection of the mass lesion where, the pathology demonstrated a highly cellular glial tumour with extensive nuclear pleomorphism and increased mitotic index consistent with a diagnosis of high-grade glioma (figure 2).

The differential diagnosis of an acute nontraumatic cortical haemorrhage in a child with NF1 includes aneurysm, haemorrhagic transformation of an ischaemic stroke and tumour. While majority of parenchymal tumours in NF-1 are low-grade astrocytomas, the rapid progression of symptoms in association with cerebral haemorrhage supported the diagnosis of a high-grade neoplasm.

NF-1 is a genetic tumour syndrome in which the neurofibromin, one of the main Ras-GAP proteins, is silenced on chr 17q11.2. Ras-GAP proteins activate Ras-GTP-hydrolase, inactivating the Ras signalling pathway that promotes cell proliferation. While low-grade astrocytomas are most commonly associated with NF-1, they are generally not haemorrhagic. Malignant gliomas have been rarely reported in children with NF-1. ${ }^{12}$ Experiments in animal models suggest that early inactivation of the P53 tumour suppressor gene may act in synergy with downstream Ras pathways to promote high grade transformation. ${ }^{3}$ Our case demonstrates the rare association of high-grade tumours with NF-1 and expands the differential diagnosis of haemorrhagic lesions in the patient population.

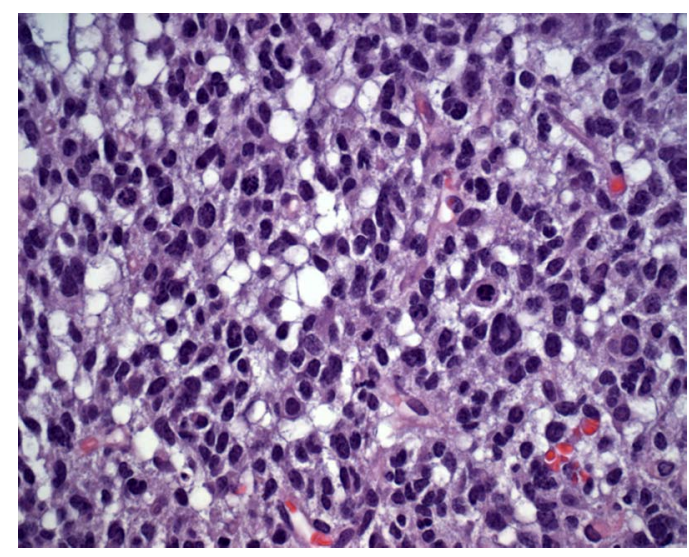

Figure 2 H\&E-stained biopsy specimen demonstrates a glial tumour with extensive nuclear pleomorphism and brisk mitotic activity in a microcystic background consistent with diagnosis of a high-grade glioma.

\section{Learning points}

- Brain tumours in children may present with intracranial haemorrhage.

- High-grade glioma is a rare tumour in association with neurofibromatosis type 1 and should be included in the differential diagnosis

\section{Competing interests None.}

Patient consent Obtained.

Provenance and peer review Not commissioned; externally peer reviewed.

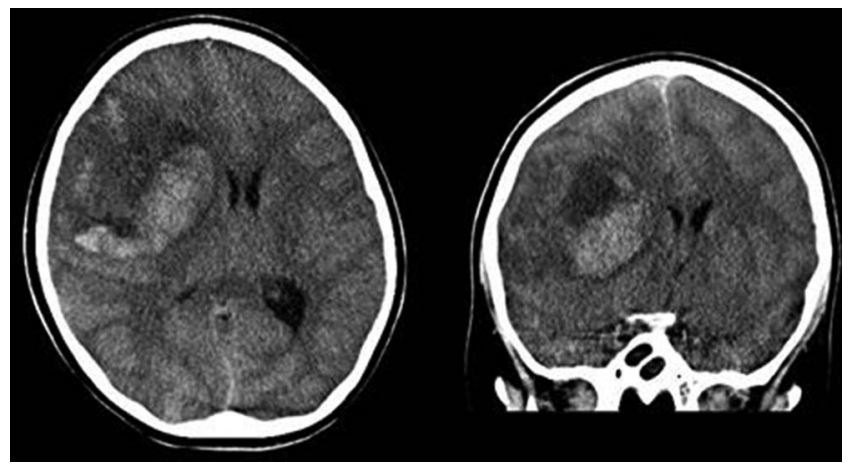

Figure 1 Preoperative head CT demonstrating a large right frontal lobar heterogeneous haemorrhage with acute and subacute components without oedema, an $8 \mathrm{~mm}$ midline shift and uncal herniation (right). 


\section{REFERENCES}

1 Huttner AJ, Kieran MW, Yao X, et al. Clinicopathologic study of glioblastoma in children with neurofibromatosis type 1. Pediatr Blood Cancer 2010;1:890-6.

2 Distelmaier $F$, Fahsold R, Reifenberger $G$, et al. Fatal glioblastoma multiforme in a patient with neurofibromatosis type 1: the dilemma of systematic medical follow-up. Childs Nerv Syst 2007;23:343-7.
3 Zhu Y, Guignard F, Zhao D, et al. Early inactivation of p53 tumor suppressor gene cooperating with NF1 loss induces malignant astrocytoma. Cancer Cell 2005;8:119-30.

Copyright 2013 BMJ Publishing Group. All rights reserved. For permission to reuse any of this content visit

http://group.bmj.com/group/rights-licensing/permissions.

BMJ Case Report Fellows may re-use this article for personal use and teaching without any further permission.

Become a Fellow of BMJ Case Reports today and you can:

- Submit as many cases as you like

- Enjoy fast sympathetic peer review and rapid publication of accepted articles

- Access all the published articles

- Re-use any of the published material for personal use and teaching without further permission

For information on Institutional Fellowships contact consortiasales@bmjgroup.com

Visit casereports.bmj.com for more articles like this and to become a Fellow 